\title{
UP TO DATE
}

\section{SEPSIS-INDUCED ACUTE KIDNEY INJURY: BIOMARKERS FOR DIAGNOSIS}

\author{
Vanessa Marcelino-Rodrigues ${ }^{1}$, Ana Caroline Silva de Freitas ${ }^{2}$, Maria José \\ Figueiredo $^{2}$, Juliana Reis Machado ${ }^{1}$, Liliana Borges de Menezes ${ }^{1}$, Danilo \\ Figueiredo Soave $e^{3}$ and Mara Rubia Nunes Celes ${ }^{1}$.
}

\section{ABSTRACT}

Sepsis is a major global health problem leading to the increased incidence of death in intensive care units. In recent years, despite technological advances, the number of cases has grown significantly. Among the main complications presented by septic patients, acute renal dysfunction is largely responsible for the high mortality rate. Initially, the reduction of renal function is associated with focal tubular injury with preserved glomerular morphology and systemic hemodynamic alterations. During sepsis development, the progressive decrease in urinary volume and reduction of the glomerular filtration rate associated with increased serum levels of urea and creatinine are considered classic markers of severe kidney injury. Despite the valuable role of these serum markers regarding renal function, these data provide an incomplete scenario of the patient, since many renal disorders may occur in individuals with increased plasma concentrations of urea and creatinine. Taking into account the important role of systemic inflammatory processes in the development of acute kidney injury induced by sepsis, the search for new markers presenting high sensitivity and specificity capable of detecting early renal injury is still necessary. Thus, the present review summarizes important aspects of pathophysiology of acute kidney dysfunction induced by sepsis and presents an updated view of possible new biomarkers associated with the development of acute kidney injury. Understanding these markers allows important advances leading to new therapeutic approaches, indicating a new horizon in the diagnosis and treatment of acute kidney injury in sepsis.

KEY WORDS: Sepsis; acute kidney injury; diagnostic biomarkers.

\footnotetext{
1. Department of Pathology, Institute of Tropical Pathology and Public Health (IPTSP), Federal University of Goias (UFG), Goias, Brazil.

2. Department of Pathology, Faculty of Medicine of Ribeirao Preto, University of Sao Paulo, SP, Brazil.

3. Department of Histology, Embryology and Cellular Biology, University of Rio Verde, Goias, Brazil.

Corresponding author: Mara Rubia N. Celes, Department of Pathology, Institute of Tropical Pathology and Public Health, Federal University of Goias, 74605-050, Goiania, Goias, Brazil. E-mail: rubia.celes@gmail.com; mrubia.celes@ufg.br
} 


\section{INTRODUCTION}

Sepsis has become the subject of many medical conferences in recent years, since despite the improvement of life support procedures in Intensive Care Units (ICUs), the development of clinical treatment indicators and diagnostic biomarkers, sepsis still remains the worldwide leading cause of death (Abraham, 2016; Vincent, 2009). According to the most recent definitions, sepsis is characterized by a combination of presumed infection plus clinical signs and laboratory findings with subsequent organ dysfunction (based on SOFA score) due to a dysregulated host response to infection (Singer et al., 2016). The heart, liver, lung and kidney are commonly affected organs during this process (Silva et al., 2004; Carvalho \& Trotta, 2003; Bone et al., 1992).

Acute renal failure, as a sepsis complication, is regarded as a problem in clinical practice and it usually occurs in hospitalized patients, especially those admitted to ICUs (10-30\%) (Patschan \& Müller, 2015; Silva et al., 2004). Despite decades of research, no specific therapy has been proposed for the treatment of acute kidney injury (AKI), other than supportive care. As a result, mortality rates have remained significantly high over the last 20 years (Patschan \& Müller, 2015; Murugan \& Kellum, 2011).

Although elegant studies have been performed to further the understanding of the pathogenesis of septic AKI, the ability to assess renal function in order to evidence an early injury is still limited. According to Murugan \& Kellum (2011), the use of new biomarkers might be predictors to increase risk stratification, simplify early diagnosis of injury, and allow therapeutic trials to assess the prognosis of injury more accurately. Thus, the aim of this review is to discuss and characterize the molecular mechanisms involved in the pathophysiology of sepsis-induced AKI, including the description of possible specific biomarkers that would greatly improve the ability to diagnose, provide prognostic information, and treat patients.

\section{PATHOPHYSIOLOGY OF ACUTE RENAL FAILURE IN SEPSIS}

The pathophysiology of AKI is considered a multifactorial complex process associated with the presence of intra-renal hemodynamic alterations, endothelial dysfunction, renal parenchymal inflammatory cell infiltration, glomerular thrombosis, and tubular obstruction by necrotic cells, leading to an abrupt decrease in the glomerular filtration rate (Wan et al., 2008). Studies in humans (Hotchkiss et al., 1999) and in animal models of sepsis and septic shock (Wu et al., 2007) have demonstrated decreased renal perfusion and worsening renal function. In septic patients, the kidneys are often among the first organs to be affected and the incidence of acute renal failure increases from $9 \%$ to $40 \%$ signifying clinical relevance (Almeida et al., 2007). 
During the sepsis progression, a serial release of inflammatory mediators, such as cytokines and chemokines, arachidonic acid metabolites, vasoactive substances, thrombogenic agents, and other biologically active mediators occurs abundantly in response to an infectious agent. Together with neuroendocrine mechanisms, these inflammatory mediators may be involved in the pathogenesis of organic dysfunction in sepsis (Wan et al., 2008). Usually, the inflammatory response is triggered when the etiological agent activates the host immune system. At first, phagocytic cells (macrophages and polymorphonuclear granulocytes) are activated by the binding of bacterial components (endotoxins of gram-negative bacteria and/or lipoteichoic acid of gram-positive bacteria) to the pattern recognition receptors (PRRs), which recognize pathogen-associated molecular patterns (PAMPs) (Flohé et al., 2006). Thereafter, these bacterial elements stimulate the activation of the inflammatory cascade with the production of large amounts of cytokines, particularly tumor necrosis factor (TNF) and interleukin-1 (IL-1) which, in turn, stimulate a strong cellular response with the release of secondary inflammatory mediators, chemotaxis, and the activation of granulocytes (Hawiger, 2001). The interaction between these mediators can cause alterations in vascular function (high levels of TNF are associated with the onset of disseminated intravascular coagulation), as well as damage to target organs, particularly the kidneys, liver, lungs, heart and central nervous system. Additionally, in some cases, resulting in death by refractory hypotension or multiple organ failure (Crouser et al., 2004).

The inflammatory mediators produced in sepsis are also the cause of renal injury and failure, which lead to an abrupt decrease in the glomerular filtration rate resulting in the inability to remove metabolites to maintain the electrolyte and acid-base balance in the body (Powell et al., 2014). Bacteria and/or bacterial products/components are capable of activating, in systemic circulation, inflammatory cells that infiltrate to the kidney. In renal tissue, these activated inflammatory cells release oxygen free radicals, cytokines and stimulate proteases that together lead to the damage and death of resident renal cells, endothelial cells, mesangial cells and tubular cells (Almeida et al., 2007).

Minimal focal tubular damage and preservation of glomerular morphology are present in the early stage of sepsis, indicating that systemic hemodynamic alterations are primarily responsible for the onset of impaired renal function (Chvojka et al., 2010). However, the septic syndrome is caused by a combination of several effects, both local and systemic, directly associated with the onset of systemic renal response leading to the production of different biologically active mediators, which cause the reduction of the renal blood flow, glomerular filtration rate, and tubular dysfunction observed in septic patients (Wan et al., 2008). 
Due to the worsening state of sepsis, acute renal dysfunction occurs, characterized by death of tubular cells due to the loss of cell integrity caused by the disruption of cell membranes and release of cytoplasmic contents. The released intracellular components can trigger an ischemia-reperfusion-induced inflammatory response (major cause of tissue damage), leading to renal dysfunction (Silva \& Otero, 2004). Nevertheless, renal tubular cell death may also occur by apoptosis. However, it is difficult to determine which lesions are caused by necrosis or apoptosis since only the absence of tubular epithelial cells is noted. The relative contribution of both death mechanisms to the initial loss of tubular cells may depend on the severity of the injury (Lerolle et al., 2010; Gill et al., 2005) since bacterial products such as LPS are able to induce tubular epithelial cell apoptosis, as well as contributing to the development of acute renal dysfunction and nephrotoxicity (Havasi \& Borkan, 2011).

Clinically, in patients with acute renal failure secondary to sepsis, decreased urine volume is noted concomitantly with decreased glomerular filtration rate and an increase in serum creatinine levels (Wan et al., 2008; Pereira et al., 1998). Glomerular filtration rate and serum creatinine level have been considered the gold standard tests for diagnosing loss of renal function in the laboratory (Pinto et al., 2012). Histopathologically, the lack of information from studies in humans due to complications during renal biopsies (Wan et al., 2008) evidences the need for studies concerning the development and validation of indirect assessment methods for analyzing tissue markers with diagnostic value that can be found in serum or urine.

\section{BIOMARKERS OF ACUTE KIDNEY INJURY IN SEPSIS}

The biomarkers used in most routine procedures in hospitals (references for the AKI diagnosis), measured in serum and/or urine, do not appear to be very sensitive or specific in detecting kidney injury in the early stage of sepsis. Thus, treatment options are limited and prognosis impaired, since there is a direct correlation between the moment of renal dysfunction diagnosis and the mortality rate resulting from complications (Malyszko, 2010).

Among the biomarkers used in clinical practice today, creatinine is the most widely used to evaluate renal function, and its dosage is the basis for the diagnosis of kidney injury; however, it does not reflect the real glomerular filtration rate (GFR). In these cases, the glomerular filtration index is potentially reduced when damage to glomeruli is installed, indicating that the products from this injury can be used as a biomarker of tissue damage. Furthermore, it is known that alterations in the GFR may not be accompanied by alterations in serum creatinine. Even though urea is another parameter used, there are studies showing that its increase is independent of serum creatinine levels (Ricci \& Ronco, 2008). A feasible solution to this problem would be to recognize the injury before the decrease in the GFR or the increase in creatinine levels (Macedo, 2011). 
The understanding of the pathogenesis of septic AKI has contributed to elucidate new biomarkers with high sensitivity and specificity. Moreover, it is important to highlight that biomarkers considered gold standard laboratory practice, are being used to evaluate other parameters, as proposed in different experimental and clinical studies (Husi \& Human, 2015; Lisowska-Myjak, 2010; Bagshaw et al., 2007). Summarizing, several proteins and biochemical markers have emerged as potential biomarkers for the detection of early septic AKI, which have shown promise in recent human studies (Chih-Yu et al., 2016; Doi et al., 2011; Han et al., 2009; Waikar et al., 2008).

The presence of kidney injury biomarkers in urine and serum is mediated by distinct pathophysiological mechanisms and according to some authors (Husi \& Human, 2015; Lisowska-Myjak, 2010) may be classified into the following: enzymes released from damaged tubular cells, low-molecularweight proteins, kidney-specific proteins involved in the development of AKI, and cytokines and chemokines.

\section{Enzymes released from damaged tubular cells}

There are six different alkaline phosphatase isoenzymes, found in the kidney, particularly on the surface of cells lining the proximal convoluted tubule of the nephron, hence forming the so-called "brush border". Their excretion in the urine increases in response to the damage to the epithelial cell membrane with loss of microvilli (Lisowska-Myjak, 2010; Bagshaw et al., 2007; Justin et al., 2003). Some enzymes such as gamma-glutamyl transpeptidase and alanine aminopeptidase are also found on the surface of proximal tubules and their concentrations are increased in urine in response to renal injury (Bagshaw et al., 2007). A study using rats with endotoxemia and absence of renal hypoperfusion showed that both enzymes are increased in the urine of the animals four hours after sepsis induction (Rao et al., 1990).

Glutathione S-transferase (GST) isozymes are cytoplasmic enzymes produced by different cell types. $\alpha$-GST is formed in renal proximal tubular epithelial cells, whereas $\pi$-GST is produced in the distal tubule and, when their levels increase independently, this may be an indication of local tissue injury. Bagshaw et al. (2011) found increased urinary GST in septic patients through a systematic review. Both enzymes ( $\alpha$-GST and $\pi$-GST) are associated with an unfavorable prognosis of acute renal dysfunction and are detectable in urine 12 hours after tissue damage (Walshe et al., 2009; Ostermann et al., 2012).

$\mathrm{N}$-acetyl- $\beta$-D-glucosaminidase (NAG) is a lysosomal enzyme serving as a specific urinary marker due to its high molecular weight $(>130 \mathrm{kDa}$, a feature that prevents its glomerular filtration); it is produced by various cells, including proximal and distal tubular epithelial cells (Ostermann et al., 2012; Mishra et al., 2003; Schmidt et al., 2007). NAG is highly concentrated in cases of tubular cell injury, and during the progression of renal diseases increased 
levels were observed 12 hours after tissue damage (Ostermann et al., 2012). Prospective studies of patients with acute tubular injury showed that increased urinary levels of NAG were associated with the need for renal replacement therapy and/or poor prognosis (Trof et al., 2006) and predicted adverse clinical outcomes in patients with acute kidney injury (Liangos et al., 2007).

The increase in NAG levels correlates directly with increased creatinine and reduced GFR, and its concentration can also be determined in the plasma (Lisowska-Myjak, 2010; Ostermann et al., 2012).

\section{Low molecular weight proteins}

The study of low molecular weight proteins, which are isolated from the urine of patients with kidney injury, has shown that they have been promising indicators of AKI for three decades (Yu et al., 1983). In general, proteins of low molecular weight $(<40 \mathrm{kDa})$ escape reabsorption when proximal tubular cells are overloaded or damaged, a feature which has allowed these proteins to be used as markers of tubular injury or dysfunction (Trof et al., 2006). Under normal conditions, low molecular weight proteins are produced at different sites and are freely filtered by the glomerulus and then reabsorbed, not being secreted by proximal tubular cells.

Retinol binding protein (RBP) has a molecular weight of $21 \mathrm{kDa}$, is bound to plasma prealbumin, and plays a role in vitamin A transport; it is mainly produced in the liver (Bagshaw et al., 2007; Donaldson et al., 1989 ). RBP is easily filtered by the glomerulus and reabsorbed in the proximal tubule. Some of the advantages of using RBP is that even a small decrease in tubular function may cause increased excretion in the urine, it is stable even in acid $\mathrm{pH}$, it does not need special care during urine sample collection and storage, and its concentration may be determined in the plasma (Lisowska-Myjak, 2010; Ostermann et al., 2012). Bagshaw et al., (2007) have classified RBP as a urinary biomarker of acute kidney injury in septic patients.

Cystatin $\mathrm{C}$ is a protein produced by every type of nucleated cell in the body whose function is to inhibit cysteine protease; it has low molecular weight $(13 \mathrm{kDa})$, it is filtered by the glomerulus and then completely reabsorbed, and its blood levels remain unchanged due to factors such as gender, muscle mass or age (Peres et al., 2013). Urinary excretion of cystatin C occurs in cases of acute tubular injury; however, due to the constant speed of production, the evaluation of cystatin $\mathrm{C}$ serum levels can be a better marker for glomerular filtration than as a marker for early acute kidney injury (Lisowska-Myjak ,2010; Bagshaw et al., 2007). Al-Beladi (2015) found that patients with sepsis showed high levels of cystatin C. Furthermore, cystatin $\mathrm{C}$ has also proved to be a good marker for the clinical stage of acute kidney injury (Minmin et al., 2015). 
Proteins specifically produced in the kidney associated with the development of acute kidney injury

Follow-up of patients with acute kidney injury showed an increase in lipocalin correlated with neutrophil gelatinase-associated lipocalin (NGAL) (Lisowska-Myjak, 2010). NGAL is a $25-\mathrm{kDa}$ protein whose physiology in the kidney is still not fully understood; it is believed to play a critical role in kidney morphogenesis (Umbro, 2016). The proteomic analysis of NGAL in animal model studies showed that this is the earliest protein with the largest production after ischemic renal injury (Nguyen \& Devarajan, 2008). Given this evidence, several clinical studies suggest that the expression of urinary NGAL may serve as an early marker for acute kidney injury (Nickolas et al., 2008). Hong et al (2015) determined plasma NGAL in order to predict its correlation with the mortality of septic patients in emergency departments. In this study, 470 patients with suspected sepsis were analyzed and, as a result, serum NGAL was found to be a valuable biological marker for severity and prognosis prediction in patients with sepsis. Lisowska-Myjak (2010) highlighted the use of NGAL as a urinary marker during the course of acute renal failure which deserves special attention since NGAL appears to be very sensitive in injury diagnosis. Westhuyzen et al. (2003) detected a significantly higher presence of NGAL in ICU patients with acute renal failure. Moreover, Schick et al. (2014) observed a significant increase in NGAL and in Cystatin $\mathrm{C}$ in experimental mice when inducing acute kidney injury after sepsis (Leelahavanichkul et al., 2016).

Kidney injury molecule-1 (KIM-1) is a recently discovered type-1 transmembrane protein that is derived from tubular cells and undetected in healthy kidneys of humans and/or animals, which was identified by using molecular biology techniques. KIM-1 has the features of an early marker for acute ischemic injury or nephrotoxic proximal tubular cell injury, which can be excreted in the urine between 12 and 24 hours after the ischemic injury. Therefore, the Food and Drug Administration (FDA) and the European Medicines Agency (EMA) qualified KIM-1 as a highly sensitive and specific urinary biomarker to verify and monitor kidney injury (Lisowska-Myjak, 2010; Vaidya et al., 2009; Malyszko, 2010; Ostermann et al., 2012)

By using immunohistochemistry, Takasu et al (2013) found increased KIM-1 expressions in septic patients. This expression was significantly higher around the corticomedullary junction of the kidney and on the apical surface of tubular epithelial cells (renal tubule brush border). 


\section{Cytokines and chemokines}

Interleukin-18 (IL-18) is a proinflammatory cytokine whose production may be induced both by injury in the proximal tubule and by caspase- 1 cleavage in the urine; it may also be found in the plasma, and it can be detected between 6 and 24 hours after kidney injury (Melnikov et al., 2001; Ostermann et al., 2012). In a systematic review of the literature, Bagshaw et al. (2007) observed that urinary IL-18 excretion was higher in septic than in non-septic individuals, so it is a predictor of renal function deterioration. Considered a clinically significant marker, IL-18 plays an important role in the early detection of acute kidney injury in sepsis.

Netrin-1 is another promising biomarker, a laminin-related neuronal guidance molecule of high molecular weight $(72 \mathrm{kDa})$ expressed in different human cells, but slightly expressed in proximal tubular cells in healthy kidneys (Ostermann et al., 2012). Under normal conditions, netrin-1 is absent in the urine and it is excreted after the onset of AKI, as shown in experimental studies (Urbschat et al., 2011). Ramesh et al. (2010) found significantly higher levels of netrin-1 in patients with sepsis-induced acute kidney injury.

\section{CONCLUSION}

In summary, despite the lack of data in the literature, studies have shown the importance of finding new biomarkers for early detection of acute renal failure. We believe that proteins specifically produced in the kidney (KIM1 and NGAL) emerge as potential molecular "markers" of sepsis-induced acute kidney injury; however more high quality studies are needed to confirm these findings. Understanding of the pathophysiology and mechanisms involved in the development of kidney injury in septic patients contributes considerably to elucidate efficient markers, which may predict the severity and progression, as well as monitor the response of the patient to treatment. Therefore, there is an increasing need to find an ideal biomarker for AKI that is sensitive, reliable, reproducible, able to distinguish between injuries, and that is applicable in clinical practice. Furthermore, it is also important to estimate the severity of the injury, to predict the progression of the disease, and to monitor the response of the patient to treatment.

\section{ACKNOWLEDGEMENTS}

MRNC is currently receiving a grant (303308/2013-3) from CNPq (Conselho Nacional de Desenvolvimento Científico e Tecnológico). LBM is currently receiving a grant (201210267001027) from FAPEG (Fundação de Amparo à Pesquisa do Estado de Goias). The excellent technical assistance of Advaldo Neto is gratefully acknowledged. 


\section{REFERENCES}

1. Abraham E. New Definitions for Sepsis and Septic Shock: Continuing Evolution but With Much Still to Be Done. Jama 315: 757-759, 2016.

2. Al-Beladi FI. Cystatin C is an Early Marker of Contrast-Induced Nephropathy in Patients with Sepsis in the Intensive Care Unit. Saudi J Kidney Dis Transpl 26: 718-724, 2015.

3. Almeida WS, Campos AH, Boim MA, Casarini DE, Schor N. Moduladores na lesão renal aguda induzida pela sepse. CIN. 2007.

4. Bagshaw SM, Langenberg C, Haase M, Li Wan, May CN, Bellomo R. Urinary biomarkers in septic acute kidney injury. Inten Care Med 33: 1285-1296, 2007.

5. Bone RC, Balk RA, Cerra FB, Dellinger RP, Fein AM, Knaus WA, Schein RM, Sibbald WJ. Definitions for sepsis and organ failure and guidelines for the use of innovative therapies in sepsis. The ACCP/SCCM Consensus Conference Committee, American College of Chest Physicians/Society of Critical Care Medicine. Chest 101:1644-1655, 1992.

6. Carvalho PR, Trotta EA. Avanços no diagnóstico e tratamento da sepse. J Pediatr 79: S195, 2003.

7. Chih-Yu H, Chi-Chung S, Kong C, Kuo-Chin K, Huang-Pin W. Predictive value of plasma neutrophil gelatinase-associated lipocalin for acute renal failure in patients with severe sepsis. J Chin Med Assoc 79: 428-434, 2016.

8. Chvojka J, Sýkora R, Karvunidis T, Raděj J, Kroužecký A, Novák I, Matějovič M.. New Developments In Septic Acute Kidney Injury. Physiol Res 59: 859-869, 2010.

9. Crouser ED, Julian MW, Huff JE, Joshi MS, Bauer JA, Gadd ME, Wewers MD, Pfeiffer DR. Abnormal permeability of inner and outer mitochondrial membranes contributes independently to mitochondrial dysfunction in the liver during acute endotoxemia. Crit Care Med 32: 478488, 2004.

10. Doi K, Negishi K, Ishizu T, Katagiri D, Fujita T, Matsubara T, Yahagi N, Sugaya T, Noiri E. Evaluation of new acute kidney injury biomarkers in a mixed intensive care unit. Crit Care Med 39: 2464-2469, 2011.

11. Donaldson MD, Chambers RE, Woolridge MW, Whicher JT. Stability of alpha -microglobulin, beta $_{2}$-microglobulin and retinol binding protein in urine. Clin Chim Acta 179: 73-77, 1989.

12. Flohé SB, Agrawal H, Schmitz D, Gertz M, Flohé S, Schade FU. Dendritic cells during polymicrobial sepsis rapidly mature but fail to initiate a protective Th1-type immune response. J Leukoc Biol 79: 473-481, 2006.

13. Gill N, Nally JV, Fatica RA. Renal failure secondary to acute tubular necrosis: epidemiology, diagnosis, and management. Chest 128: 2847-2863, 2005.

14. Han WK, Wagener G, Zhu Y, Wang S, Lee HT. Urinary Biomarkers in the Early Detection of Acute Kidney Injury after Cardiac Surgery. Clin J Am Soc Nephrol 4: 873-882, 2009.

15. Havasi A, Borkan SC. Apoptosis and acute kidney injury. Kidney Int 80: 29-40, 2011.

16. Hawiger J. Innate immunity and inflammation: a transcriptional paradigm. Immunol Res 23: 99-109, 2001.

17. Hong DY, Kim JW, Paik JH, Jung HM, Baek KJ, Park SO, Lee KR.Value of plasma neutrophil gelatinase-associated lipocalin in predicting the mortality of patients with sepsis at the emergency department. Clin Chim Acta 5: 177-178, 2016.

18. Hotchkiss RS, Swanson PE, Freeman BD, Tinsley KW, Cobb JP, Matuschak GM, Buchmam T, Karl I. Apoptotic cell death in patients with sepsis, shock, and multiple organ dysfunction. Crit Care Med 27: 1230-1251, 1999. 
19. Husih H, Human C. Molecular determinants of acute kidney injury. J Inj Violence Res 7: 7586, 2015.

20. Justin W, Zoltan HE, Graham R, David MR, David S, Thomas JM. Measurement of tubular enzymuria facilitates early detection of acute renal impairment in the intensive care unit. Nephrol Dial Transplant 18: 543-551, 2003.

21. Leelahavanichkul A, Somparn P, Issara-Amphorn J, Eiam-ong S, Avihingsanon Y, Hirankarn N, Srisawat N. Serum Neutrophil Gelatinase Associated Lipocalin (NGAL) Outperforms Serum Creatinine in Detecting Sepsis-Induced Acute Kidney Injury, Experiments on Bilateral Nephrectomy and Bilateral Ureter Obstruction Mouse Models. Shock 45: 570-576, 2016.

22. Lerolle N, Nochy D, Guérot E, Bruneval P, Fagon JY, Diehl JL, Hill G. Histopathology of septic shock induced acute kidney injury: apoptosis and leukocytic infiltration. Inten Care Med 36: 471-478, 2010.

23. Liangos O, Perianayagam MC, Vaidya VS, Han WK, Wald R, Tighiouart H, MacKinnon RW, Li L, Balakrishnan VS, Pereira BJ, Bonventre JV, Jaber BL. Urinary N-acetyl-beta(D)-glucosaminidase activity and kidney injury molecule-1 level are associated with adverse outcomes in acute renal failure. J Am Soc Nephrol 18: 904-912, 2007.

24. Lisowska-Myjak B. Serum and Urinary Biomarkers of Acute Kidney Injury. Blood Purif 29: 357-365, 2010.

25. Macedo E. Biomarcadores da Injúria Renal Aguda. Sociedade Brasileira de NefrologiaBiomarcadores na Nefrologia: São Paulo. 2011. p.19-32.

26. Malyszko J. Biomarkers of Acute Kidney Injury in Different Clinical Settings: A Time to Change the Paradigm? Kidney Blood Press Res 33: 368-382, 2010.

27. Melnikov VY, Ecder T, Fantuzzi G, Siegmund B, Lucia MS, Dinarello CA, Schrier RW, Edelstein CL. Impaired IL-18 processing protects caspase-1-deficient mice from ischemic acute renal failure. J Clin Invest 107: 1145-1152, 2001.

28. Minmin G, Yibin Y, Shixian Z. Value of acute renal injury associated biomarkers for patients in intensive care unit. J Cent South Univ 40: 1083-1088, 2015.

29. Mishra J, Ma Q, Prada A, Mitsnefes M, Zahedi K, Yang J, Barasch J, Devarajan P. Identification of Neutrophil Gelatinase-Associated Lipocalin as a Novel Early Urinary Biomarker for Ischemic Renal Injury. J Am Soc Nephrol 14: 2534-2543, 2003.

30. Murugan K, Kellum JA. Acute kidney injury: what's the prognosis? Nat Rev Nepho 7: 209217, 2011.

31. Nguyen MT, Devarajan P. Biomarkers for the early detection of acute kidney injury. Pediatr Nephrol 23: 2151-2157, 2008.

32. Nickolas TL, O'rourke MJ, Yang J, Sise ME, Canetta PA, Barasch N, Buchen C, Khan F, Mori K, Giglio J, Devarajan P, Barasch J. Sensitivity and specificity of a single emergency department measurement of urinary neutrophil gelatinase-associated lipocalin for diagnosing acute kidney injury. An Intern Med 148: 810-819, 2008.

33. Ostermann M, Philips BJ, Forni LG. Clinical review: Biomarkers of acute kidney injury: where are we now? Crit Care 16: 1-13, 2012.

34. Patschan D, Müller GA. Acute kidney injury. J Inj Violence Res 7: 19-26, 2015.

35. Pereira GA, Marson F, Abeid M, Ostini FM, Souza SH, Basile-Filho A. Fisiopatologia da sepse e suas implicações terapêuticas. Rev Med 31: 349-362, 1998.

36. Peres LAB, Cunha Júnior AD, Schäfer AJ, Silva AL, Gaspar AD, Scarpari DF, Alves JBF, Girelli Neto R, Oliveira TFT. Biomarcadores da injúria renal aguda. J Bras Nefrol 35: 229-236, 2013.

37. Pinto CF, Watanabe M, Fonseca CD, Ogata CI, Vattimo MD. A sepse como causa de lesão renal aguda: modelo experimental. Rev Esc Enferm USP 46: 86-90, 2012. 
38. Powell CT, Powell SL, Allen BK, Griffin RL, Warnock DG, Wang HE. Association of inflammatory and endothelial cell activation biomarkers with acute kidney injury after sepsis. Springer Plus 3: 1-8, 2014.

39. Ramesh G, Krawczeski CD, Woo JG, Wang Y, Devarajan P. Urinary netrin-1 is an early predictive biomarker of acute kidney injury after cardiac surgery. Clin J Am Soc Nephrol 5: 395-401, 2010.

40. Rao PS, Cavanagh DM, Fiorica JV, Spaziani E. Endotoxin-induced alterations in renal function with particular reference to tubular enzyme activity. Circ Shock 31: 333-342, 1990.

41. Ricci Z, Ronco C. Pathogenesis of Acute Kidney Injury During Sepsis. Current Drug Targets 10: 1179-1183, 2009.

42. Schick MA, Baar W, Flemming S, Schlegel N, Wollborn J, Held C, Reinhard Schneider R, Brock RW, Roewer N, Wunder C. Sepsis-induced acute kidney injury by standardized colon ascendens stent peritonitis in rats - a simple, reproducible animal model. Crit Care 2: 1-17, 2014.

43. Silva E, Otero JB. Disfunção de Múltiplos Órgãos. Rev Bras Ter Intensiva 16: 114-118, 2004.

44. Silva E, Pedro MA, Sogayar ACB, Mohovic T, Silva CLO, Janiszewski M, Cal RGR, Sousa EF, Abe TP, Andrade J, Matos JD, Rezende E, Assunção M, Avezum A, Rocha PCS, Matos GFJ, Bento AM, Corrêa AD, Vieira PCB, Knobel E. Brazilian Sepsis Epidemiological Study. Crit Care 8: 251-260, 2004.

45. Singer M, Deutschman CS, Seymour CW, Shankar-Hari M, Annane D, Bauer M, Bellomo R, Bernard GR, Chiche JD, Coopersmith CM, Hotchkiss RS, Levy MM, Marshall JC, Martin GS, Opal SM, Gordon D. Rubenfeld GD, Poll TVD, Vincent JL, Angus DC. The Third International Consensus Definitions for Sepsis and Septic Shock (Sepsis-3). Jama 315: 801$810,2016$.

46. Schmidt-Ott KM, Mori K, Li JY, Kalandadze A, Cohen DJ, Devarajan P, Barasch J. Dual action of neutrophil gelatinase-associated lipocalin. J Am Soc Nephrol 18: 407-413, 2007.

47. Takasu O, Gaut JP, Watanabe E, To K, Fagley RE, Sato B, Jarman S, Efimov IR, Janks DL, Srivastava A, Bhayani SB, Drewry A, Swanson PE, . Hotchkiss RS. Mechanisms of Cardiac and Renal Dysfunction in Patients Dying of Sepsis. Am J Resp Crit Care Med 187: 509-517, 2013.

48. Trof RJ, Maggio FD, Leemreis J, Groeneveld AB. Biomarkers Of Acute Renal Injury And Renal Failure. Shock 26: 245-253, 2006.

49. Umbro I, Gentile G, Tinti F, Muiesan P, Mitterhofer AP. Recent advances in pathophysiology and biomarkers of sepsis-induced acute kidney injury. $J$ Infect 72: 131-142, 2016.

50. Urbschat A, Obermuller N, Haferkamp A. Biomarkers of kidney injury. Biomarkers 1: S22-S30, 2011.

51. Vaidya VS, Ford GM, Waikar SS, Wang Y, Clement MB, Ramirez V, Glaab WE, Troth SP, Sistare FD, Prozialeck WC, Edwards JR, Bobadilla NA, Mefferd SC, Bonventre JV. A rapid urine test for early detection of kidney injury. Kidney Int 1:108-14, 2009.

52. Vincent JL. Yearbook of intensive care and emergency medicine. Springer: Heidelberg. 2009. p.183-194.

53. Waikar SS, Liu KD, Chertow GM. Diagnosis, epidemiology and outcomes of acute kidney injury. Clin J Am Soc Nephrol 3: 844-861, 2008.

54. Walshe CM, Odejayi F, Ng S, Marsh B. Urinary glutathione S-transferase as an early marker for renal dysfunction in patients admitted to intensive care with sepsis. Crit Care Resusc 11: 204-249, 2009.

55. Wan L, Bagshaw SM, Langenberg C, Saotome T, May C, Bellomo R. Pathophysiology of septic acute kidney injury: What do we really know? Crit Care Med 36: S198-S203, 2008. 
56. Westhuyzen J, Endre ZH, Reece G, Reith DM, Saltissi D, Morgan TJ. Measurement of tubular enzymuria facilitates early detection of acute renal impairment in the intensive care unit. Nephrol Dial Transplant 18: 543-551, 2003.

57. Wu L, Tiwari MM, Messer KJ, Holthoff JH, Gokden N, Brock RW, Mayeux RP. Peritubular capillary dysfunction and renal tubular epithelial cell stress following lipopolysaccharide administration in mice. Am J Physiol Renal Physio 292: 261-268, 2007.

58. Yu H, Cooper EH, Settle JA, Meadows T. Urinary protein profiles after burn injury. Burns Incl Therm Inj 9: 339-349, 1983. 